\title{
STYLOSANTHES CAPITATA GERMINATION RESPONSE TO ENVIRONMENTAL AND CHEMICAL STIMULUS
}

\section{Oscar Mitsuo Yamashita ${ }^{1 *}$, Rodrigo da Silva Petry ${ }^{2}$, Fabio Henrique Rojo Baio $^{3}$, Cassiano Garcia Roque ${ }^{3}$, Marco Antonio Camillo de Carvalho ${ }^{1}$, Rivanildo Dallacort ${ }^{2}$}

\author{
${ }^{1}$ Faculdade de Ciências Biológicas e Agrárias e do Programa de Pós-graduação em Biodiversidade e Agroecossistemas Amazônicos da Universidade do Estado \\ de Mato Grosso - Campus de Alta Floresta - MT \\ ${ }^{2}$ Representante da Sipcam-Nichino do Brasil. Vila Bela da Santissima Trindade, Vila Rica - MT. \\ ${ }^{3}$ Curso de Agronomia da Universidade Federal de Mato Grosso do Sul, Campus de Chapadão do Sul - MS \\ *Autorpara correspondência:yama@unemat.br
}

Recebido em 30 de novembro de 2015. Aceito em 06 de junho de 2018. Publicado em 26 de dezembro de 2018.

\begin{abstract}
Aвstract - The fast crop establishment is very important to the leguminous (Fabaceae), especially if they were seeded in consort pastures with grass (Gramineae), where the seeds germination process on the field are guided by a group of environmental factors. The purpose of this work was to evaluate and to study these conditions, as for temperature, luminosity, hydric and saline stresses and aluminum concentration to the germination of Stylosanthes capitata. Studies were guided in laboratory to obtain certain conditions, and then the germination speed index (GSI) was evaluated. The experimental design was completely randomized. The species showed a significant sensibility to high temperatures, where the better was around 25 ${ }^{\circ} \mathrm{C}$. In addition, the species showed to be indifferent to the brightness, although, the seeds tended to respond positively to the absence of light. The hydric stress and saline effects were harmful to the germination percentage due to the increase of the osmotic potential in the solution. The germination percentage was reduced with the increase of the aluminum concentration; however, this effect was not statistically significant. Data are important and contribute to studies aiming at the propagation of the species.
\end{abstract}

KeYwords: Estilos ANTES, STRESS, SEEDS.

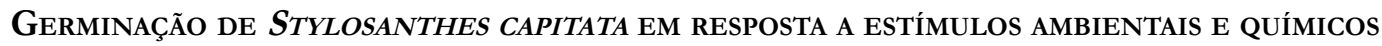

Resumo - O rápido estabelecimento da cultura é muito importante para as leguminosas (Fabaceae), principalmente se estas foram semeadas em consórcio de pastagens com gramíneas, onde o processo de germinação das sementes em campo são regidos por um conjunto de fatores ambientais. O objetivo deste trabalho foi avaliar e estudar estas condições, tais como: temperatura, luminosidade, estresses hídrico e salino e concentração de alumínio na germinação de Stylosanthes capitata. Os experimentos foram conduzidos em laboratório para cada uma das condições e, em seguida, determinou-se a porcentagem de germinação, o índice de velocidade de germinação (IVG). O delineamento experimental foi inteiramente casualizado. As espécies mostraram uma sensibilidade significativa a altas temperaturas, onde o melhor foi em torno de $25^{\circ} \mathrm{C}$. Além disso, as espécies mostraram-se indiferentes à luminosidade, embora as sementes tenderam a responder positivamente à ausência de luz. O estresse salino e efeitos hídricos foram prejudiciais para a germinação, em função do incremento do potencial osmótico na solução. A porcentagem de germinação foi reduzida com o aumento da concentração de alumínio; no entanto, este efeito não foi significativo. Os dados são importantes e contribuem para estudos que visem a propagação da espécie.

Palavras-chave: Estilos antes, Estresse, Sementes. 


\section{Germinación de STYLOSANTHES CAPITATa EN RESPUESTA A ESTÍMUlos AMBIENTALES y Químicos}

Resumen - El rápido establecimiento de la cultura es muy importante para las leguminosas (Fabaceae), principalmente si éstas se sembraron en asociación de pastos con gramíneas, donde el proceso de germinación de las semillas en campo se rige por un conjunto de factores ambientales. El objetivo de este trabajo fue evaluar y estudiar estas condiciones, tales como: temperatura, luminosidad, estrés hídrico y salino y concentración de aluminio en la germinación de Stylosanthes capitata. Los experimentos se realizaron en laboratorio para cada una de las condiciones y, a continuación, se determinó el porcentaje de germinación, el índice de velocidad de germinación (IVG). El delineamiento experimental fue completamente aleatorizado. Las especies mostraron una sensibilidad significativa a altas temperaturas, donde el mejor fue alrededor de $25^{\circ} \mathrm{C}$. Además, las especies se mostraron indiferentes a la luminosidad, aunque las semillas tendieron a responder positivamente a la ausencia de luz. El estrés salino y los efectos hídricos fueron perjudiciales para la germinación, en función del incremento del potencial osmótico en la solución. El porcentaje de germinación se redujo con el aumento de la concentración de aluminio; sin embargo, este efecto no fue significativo. Los datos son importantes y contribuyen a estudios dirigidos a la propagación de la especie.

Palabras clave: Estilos, Estrés, Semillas.

\section{INTRODUCTION}

With the increment of the growth population and of the need for food production, it is more than necessary to increase the crop yield allied to profit and agricultural systems sustainability.

The nitrogen is one of the main restricted factors to the increment or conservation of the yield in tropical soils and degraded areas (Nóbrega \& Nóbrega 2003). The biological nitrogen fixation (FBN) done by the association of rhizobium and leguminous is a profit nitrogen source and not environmental polluter (Purcino et al. 2005), allowing increments on the vegetal mass production in grasses areas, in view of the chemical fertilizer application of nitrogen may not bring back the desired economical return, by the inadequacy of this type of area to the establishment of intensive systems to cattle production (Branco et al. 2000).

Thus, estilosantes forage leguminous (Stylosanthes capitata) is indicated to the association with grass in pasture areas. This species shows high forage production potential and is a very adapted protein source related to sandy soils with low fertility, like the Brazilian cerrados (Embrapa 2000). According to Embrapa (2002), this leguminous shows high capacity to adapt in low fertilized soils, shows high yield potential, which can achieve in between 12 and 13 tons per hectare year of dry matter, shows the capacity to acquire large quantity of nitrogen by biological fixation, which is done by the association of its roots with the bacteria from Rhizobium genus. Besides, it has several others important agronomical characteristics like high seed dissemination capacity, Bracbiaria decumbens association persistency, excellent digestibility to cattle and natural defoliation tolerance. It is also environmentally accepted, once reduces the use of nitrogen chemical fertilizer, obtained from petroleum, which is not replaceable and with high commercial cost (Embrapa 2002).

The implantation has a significative importance to the formation or regeneration of an associated grass with leguminous. On this context, the seed germination is a limiting factor because the seed has all yield potentialities of the plant (Macedo et al. 2005). So, by this reason, the seed is considered one of the most important agricultural inputs (Popinigis 1985).

The germination capacity of a seed lot is shown by the seed proportion that can produce normal seedlings in favorable conditions. However, not always the soil conditions to the seeds germination are optimum (MarcosFilho 1994). The germination process is affected by a series of intrinsic and extrinsic conditions (Mayer and Poljakoff-Mayber 1989), such as the environmental factors that can determine a bigger or smaller germination index, and consequently, the number of new plants on the field. Factors related to the weather, such as light 
and temperature, and related to the soil condition, such as $\mathrm{pH}$, saline level and moisture have been appointed as the seeds germination controllers (Carvalho \& Nakagawa 2000), impacting, decisively, on the species dynamic population, advancing those with bigger ability to germinate under stress condition, and at the same time, limiting those with bigger sensibility (Marcos-Filho 1994). The recognition of the environmental factors, related to the weather and soil, that controls the germination behavior of the seeds has a fundamental role to the interpretation of the ecological species behavior on the field, in addition, helps on the development of strategies targeting the increment acceleration of new plants on the field.

The purpose of this work was to identify the variation that occurs related to the seed germination of estilosantes (Stylosanthes capitata) in function of temperature, irradiance, hydric and saline stresses and aluminum concentration on the substratum.

\section{Material and Methods}

The research was conducted in between February and May, 2008, at the seeds laboratory of Mato Grosso State University - UNEMAT, Alta Floresta Campus, Brazil.

The seeds skin used were already scratched to the experiment, obtained from the local market. The germination tests were based on the general instructions contained on the Brazilian Seeds Analyses Rules (Brasil 2009), with 4 repetitions with 50 sampled seeds each, summarizing 200 seeds per treatment. The seeds were treated with sanitary water (active chloride at $2 \%$ ) at $1 / 4$ of the solution, submerged by a period of 10 minutes.

\section{Temperature and Light}

Translucent acrylic boxes, "gerbox" type $(11,5 \times 11,5 \times 3,5 \mathrm{~cm})$, were used to evaluate the temperature and light conditions effects. These boxes allowed the light passage, characterizing the light treatment; and by the use of black boxes with the same dimensions and material the light passage was interrupted, characterizing the dark treatment. The seeds were seeded over two sheets of "germitest" paper, disposed inside these boxes and humidified with a distillated water quantity equivalent to 2,5 times the paper weight (Brasil 2009). Then, the experiment was kept inside germination chamber with controlled temperature, B.O.D type model Tecnal ${ }^{\circledR}$ TE-401. The temperature in laboratory bench conditions was measured using a thermohygrometer (model Springfield ${ }^{\circledR}$ PreciseTemp) and varied between 17 and $35^{\circ} \mathrm{C}$ throughout the experiment. The light period was regulated to $12 \mathrm{~h}$ of light. The humidity condition varied from 42 to $71 \%$.

To the light treatments, daily evaluations were made, always at the same time, taking off the germinated seeds, during 10 days of evaluation.

On the treatments without light, the replications were kept on this condition by 4 days and so, the nongerminated seeds were transferred to the acrylic boxes by more 6 days, with temperature and irradiance similar to the light treatment. The seeds with root extension $\geq 2 \mathrm{~mm}$ were considered germinated.

All data were submitted to the analyses of variance. The germination were analyzed under two aspects: the percentage of germination and the germination speed index (GSI). All germination percentage data were previously transformed by the $(x+0,5)$ root. The variance homogeneity and the normal distribution of the data were obtained by this transformation. The GSI was calculated according to Maguire et al. (1962), from the equation: GSI $=[\mathrm{N} 1 / 1+\mathrm{N} 2 / 2+\mathrm{N} 3 / 3+\ldots+\mathrm{Nn} / \mathrm{n}] \times 100$, where: N1, N2, N3 and Nn are the portion of the seeds germinated on the first, second, third and umpteenth day after the seed. Data were submitted to ANOVA and the means comparison was performed by the Tukey test, at $5 \%$ probability. 


\section{Hydric and saline stresses}

The treatments to the effects of the hydric and saline stresses over the seeds germination were analyzed using aqueous solution with osmotic potential of $0.0,-0.2,-0.4,-0.6$, and $-1.0 \mathrm{MPa}$, mixing poliethyleneglycol 6.000 (PEG) and $\mathrm{NaCl}$ with distilled water. The control treatment $(0.0 \mathrm{MPa})$ was made with distilled water only. The chemical compost poliethyleneglycol is an osmotic agent without adverse effects to the seeds, chemically inert, non-toxic, with high molecular weight (hard to be absorbed) and has providing hydric restriction to the seeds, according to the concentration (Braccini et al. 1996; Yamashita et al. 2009).

The seeds were seeded over two sheets of "germitest" paper, disposed inside translucent acrylic boxes, "gerbox" type $(11,5 \times 11,5 \times 3,5 \mathrm{~cm})$ and humidified with $15 \mathrm{~mL}$ of the aqueous solution with osmotic potential equivalent to the treatment. They were tight with translucent plastic film. The experiment was kept inside germination chamber, B.O.D type model Tecnal ${ }^{\circledR}$ TE-401, with controlled temperature at $25^{\circ} \mathrm{C}$. The light period was regulated to $12 \mathrm{~h}$ of light.

The experiment was monitored during 10 days, with counting on the fifth and tenth day, taking off the germinated seeds. The germination was analyzed according to its percentage, considering germinated seeds those that showed root extension $\geq 2 \mathrm{~mm}$. The experimental design was the same to all treatments, completely randomized. The collected data were submitted to analysis of variance (test F), comparing the means by the Tukey test at $5 \%$ of probability. The quantitative variables were submitted to regression analysis, seeking to present a mathematical explanation for the effect.

\section{Aluminum concentration}

The treatments to evaluate the effects of the aluminum concentration over the seed germination were prepared mixing aluminum sulfate $\left(\mathrm{Al}_{2} \mathrm{SO}_{4}\right)$ with distilled water at $0.5,1.0,1.5,2.0 \mathrm{~mol}_{\mathrm{c}} \mathrm{L}^{-1}$ of concentration. The control treatment had only distilled water. It was used the same method of the hydric stress and saline condition treatments.

\section{Experimental Design}

The experimental design in all experiments was the completely randomized in a $3 \times 2$ factorial, with four replications. The treatments were made by the factorial combination consequence from three levels of temperatures $\left[25^{\circ} \mathrm{C}, 30{ }^{\circ} \mathrm{C}\right.$ and natural laboratory temperature (varied between 17 and $35^{\circ} \mathrm{C}$ )] and two light conditions (with and without light).

\section{Results AND Discussion}

\section{Temperature and light condition}

By the obtained results, the species cannot be entitled as positive photoblastic, because significant differences were not observed in between the treatments with light and dark, on the tested conditions of temperatures.

The averages of germination remained between 62 and 79\% and the GSI between 5 and 7 . The highest values were obtained at $25{ }^{\circ} \mathrm{C}$. Although, it was not observed statistical difference between light and dark, the seeds 
showed a trend to positively answer to the absence of light and temperature variation. The dark condition showed to promote seed germination of Stylosanthes capitata, but not as a factor (Table 1 and 2).

Table 1. Germinative percentages (\%) of Stylosanthes capitata seeds submitted to thermal and light conditions. Alta Floresta- MT, Brazil. 2008.

\begin{tabular}{cccc}
\hline \multirow{2}{*}{ Light Condition } & \multicolumn{3}{c}{ Temperature } \\
\cline { 2 - 4 } & No control & $\mathbf{2 5}^{\mathbf{}} \mathbf{C}$ & $\mathbf{3 0}^{\mathbf{0}} \mathbf{C}$ \\
\hline Light & $69,6 \mathrm{Aa}$ & $78,6 \mathrm{Aa}$ & $52,2 \mathrm{Ba}$ \\
Dark & $72,0 \mathrm{Aa}$ & $75,0 \mathrm{Aa}$ & $61,8 \mathrm{Aa}$ \\
\hline C.V. (\%) & & 11,93 & \\
\hline
\end{tabular}

Averages followed by the same lower case letter do not differ inside each temperature condition and the same upper case do not differ inside each light condition by Tukey's test at $5 \%$ of significance.

Table 2. Germination Speed Index (GSI) of Stylosanthes capitata seeds under thermal levels and light conditions. Alta Floresta- MT, Brazil. 2008.

\begin{tabular}{cccc}
\hline \multirow{2}{*}{ Light Condition } & \multicolumn{3}{c}{ Temperature } \\
\cline { 2 - 4 } & No control & $\mathbf{2 5}^{\mathbf{}} \mathbf{C}$ & $\mathbf{3 0}^{\mathbf{}} \mathbf{C}$ \\
\hline Light & $6,50 \mathrm{Aa}$ & $7,83 \mathrm{ABa}$ & $5,23 \mathrm{Ba}$ \\
Dark & $7,22 \mathrm{Aa}$ & $7,06 \mathrm{Aa}$ & $5,93 \mathrm{Aa}$ \\
\hline C.V. (\%) & & 12,94 \\
\hline
\end{tabular}

Averages followed by the same lower case letter do not differ inside each temperature condition and the same upper case do not differ inside each light condition by Tukey's test at $5 \%$ of significance.

The Brazilian rules to the seeds analyzes inform about the seeds sensibility to the light, defining that several species economically important germinate as much as on the presence and the absence of light (Brasil 2009). The promotion or inhibition of the germination affected by the light is a result of a chemical reaction, regulated by the phytochrome (Takaki 2001), and on this species presents germination independent of the presence of light, but that alternating temperatures or slightly higher temperatures may promote an increase in germination capacity. This can be an indicative that this species may respond differently under these conditions, in other words, with inadequate conditions or alternating temperatures the seeds can germinate even more, even if kept under light absence. According to Popinigis (1985), the seeds of the majority of the cropped plants germinate equally on the absence or presence of light, however, when the light presence is required to the germination, this behavior is related to some type of dormancy. Several species exhibit this same behavior (Brazil, 2009).

The different species have different temperature sensibilities to germinate, and high temperatures can be supported by some species but not by others (Mayer and Poljakoff-Mayber 1989). This temperature range for germination can vary within the optimal zones according to each species. However, temperatures higher than this zone, reaching values higher than $35^{\circ} \mathrm{C}$ in some cases, have been reported as inhibitors of the germination process.

Several studies showed that the optimum germination temperature to the majority of the seeds is in between 15 and $30^{\circ} \mathrm{C}$ and the maximum temperature is around the $25^{\circ} \mathrm{C}$ zone (Vasquez-Yanes \& Orozco-Segovia 1982; Faron et al. 2004; Abreu and Garcia 2005; Lopes and Lima 2005). The seeds can die if the temperature goes above the maximum limit (Borges e Rena, 1993). If there are no other limiting factors, the germination occurs within certain temperature limits, which extremes are dependent of the cropped species mainly (Toledo \& Marcos-Filho 1977). Añez et al. (2002) attribute that the negative effect of the high temperatures for long periods over the germinative process to the decrement of the free amino acids provision, decrement of RNA syntheses and protein, and the decrement of the metabolic reactions, which can delay or suppress the germination, or even let to the seed viability loss. According to Marcos-Filho (2005), the effects of high temperatures by long times is restrictive to the 
germination and can be explained by possible enzymatic changes, by the seed physiological condition or by the insolubility of the oxygen on these conditions, increasing its exigency and accelerating the seed respiration rate.

According to the results, it is possible to infer some techniques for the crop implantation, considering that they can be seeded on the presence or on the absence of the light and exposed to the constant temperatures with average around $25^{\circ} \mathrm{C}$.

\section{Hydric and saline stresses}

The hydric and saline stresses produced by the negative osmotic potential created by both PEG 6000 and $\mathrm{NaCl}$ solutions, exerted significative effect on Stylosanthes capitata germination. The seeds had their germinative capacity affected by the osmotic potential, with significant reduction even from the smaller studied potential $(-0,2$ $\mathrm{MPa}$ ), being more pronounced in $\mathrm{NaCl}$ than in PEG 6000. The reduction curve followed a quadratic trend in both used products (Figures 1 and 2) as the osmotic potential decreased.

Figure 1. Accumulated germinative percentage of Stylosanthes capitata seeds, in PEG 6000 solutions with several osmotic potential. Alta Floresta-MT, Brazil. 2008.

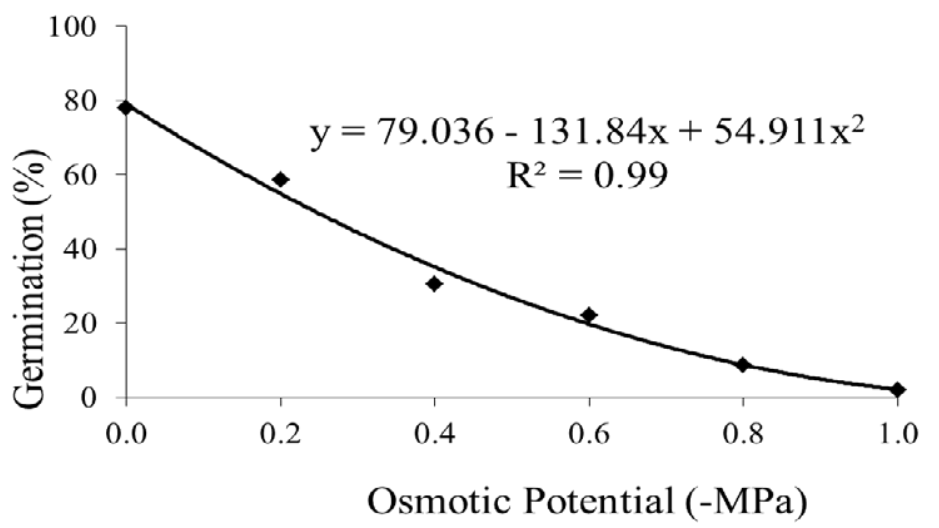

Figure 2. Accumulated germinative percentage of Stylosanthes capitata seeds, in $\mathrm{NaCl}$ solutions with several osmotic potential. Alta Floresta-MT, Brazil. 2008.

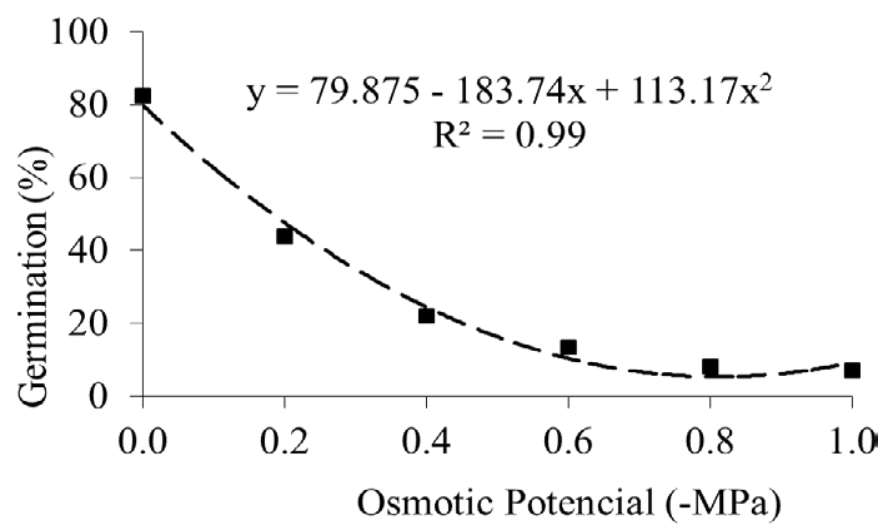

This effect when PEG solution was used can be explained by the high PEG molecular weight, which is not absorbed, showing high viscosity, which accreted to the low $\mathrm{O}_{2}$ diffusion rate, can compromise the availability of oxygen to the seeds during the germinative process (Braccini et al. 1996).

Braga et al. (2008) attribute to the $\mathrm{Na}^{+}$ion the seed capacity to increment the membrane permeability and decrement the absorption selectivity. Thus, the exposed seeds to the $\mathrm{NaCl}$ solution could increment their rate of absorption by altering the permeability, with consequent differences on the germinative process. 
The reduction on the seeds germination submitted to the hydric stress is attributed to the reduction on the enzymatic activity, which promotes a reduction on the meristematic development, while the salinity affects the germination, not only hinder the water absorption kinetics, but also facilitating the entrance of ions in toxic quantity on the soaking seeds (Santos et al. 1992; Braccini et al. 1996).

Salts inhibit seeds reserves mobilization and can affect negatively the enzyme activities responsible by hydrolyze and translocation of products from the reserve tissues to the embryonic pivot, thus, affecting the germination process (Prisco et al. 1981). Beside the osmotic and toxic effects, the salinity tolerance involves from the protoplasm tolerance to the disturbers on the ionic balance associated to the saline stress, which depends of the vegetal species (Bewley \& Black 1994).

The effects were outstanding when the seeds were placed on the moistened substrate containing saline solutions. Similar results were found by Santos et al. (1992) to soybean seeds and by Torres et al. (2000) to cucumber seeds. These authors, despite they observed a decrement on the germination percentage, they observed a significative increment on the abnormal seedlings, in function of the osmotic potential reduction and the increment on the substrate saline concentration.

\section{Aluminum concentration}

The results of the Stylosanthes capitata germination are in Figure 3, which shows the germinative percentage in function of the levels of the $\mathrm{Al}_{2} \mathrm{SO}_{4}$ concentration on the solution.

It was verified a decrement on the germinative percentage related to the increment on the aluminum concentration, following a linear decrement trend $(y=-15 x+78,1)$ on the reduction of the seeds germination.

Figure 3. Accumulated germinative percentage of Stylosanthes capitata seeds, in $\mathrm{Al}_{2} \mathrm{SO}_{4}$ solutions with several concentrations. Alta Floresta-MT, Brazil. 2008.

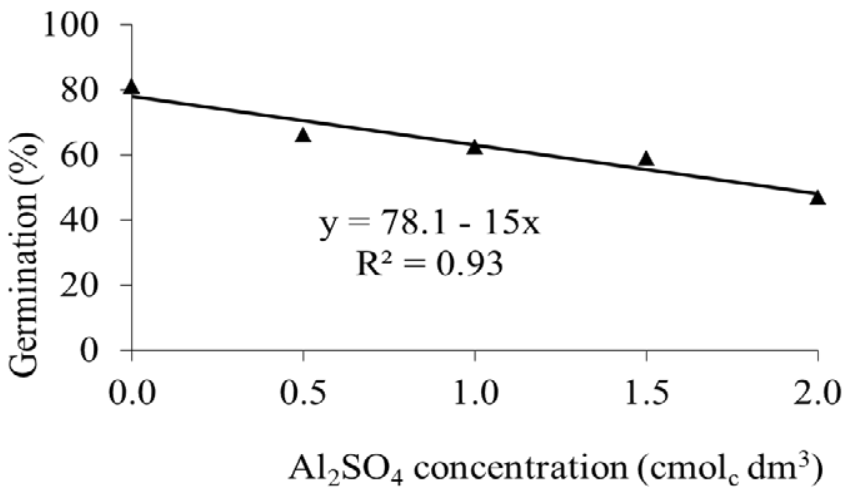

It was observed a high percentage of abnormal seedlings, especially at the highest studied concentration. Besides, the seedlings radicles in all studied concentration showed necrotic tissue at their extremity, indicating the harmful effect of this salt when in contact with them.

The reviewed literature has few information available about the effects of the aluminum over the seed germination. The information is practically nonexistent when considered its effects on the forage leguminous seeds. However, despite the fact that the aluminum compromises some cellular metabolism processes, such as those related to the protein syntheses, permeability of water, lipids mobilization, cellular division and cellular tissue syntheses, indicates that it has potential to negatively affect the seed germination (Roy et al. 1988; Dutra and SouzaFilho 1998; Custódio et al. 2002).

Results gathered from this work indicate that high changeable aluminum concentration on soils, which presented values of $\mathrm{pH}$ below 4.4, can affect the seedling establishment of Stylosanthes capitata, since the germinative process, reducing rate and percentage of germination. 


\section{Conclusions}

The germination of Stylosanthes capitata seeds is significantly influenced by temperatures above $30^{\circ} \mathrm{C}$, presenting better germination at $25^{\circ} \mathrm{C}$ constants.

The seeds of this species are photoblastic neutral with no significant difference on the germination in dark condition.

The progressive reduction of the osmotic potential by the use of PEG 6000 and $\mathrm{NaCl}$ is prejudicial to the germination of Stylosanthes capitata, and their effects are accented from -0.4 MPa.

The presence of aluminum from $0.5 \mathrm{cmol} \cdot \mathrm{dm}^{-3}$ reduces the germination of Stylosanthes capitata seeds.

\section{REFERENCES}

Abreu M.E.P. and Garcia Q.S. 2005. Efeito da luz e da temperatura na germinação de sementes de quatro espécies de Xyris L. (Xyridaceae) ocorrentes na Serra do Cipó, MG, Brasil. Acta Botânica Brasílica 19(1):149-154.

Añez L.M.M., Vaden E.R., Oliveira S.S., Albuquerque M.C.F. and Coelho M.F.B. 2002. Temperaturas para germinação de sementes de mama-cadela (Brosimum gaudichaudii Trec - Moraceae). Revista Agricultura Tropical 6:167-176.

Bewley, J.D. and Black M. 1994. Seeds: physiology of development and germination. 2.ed. New York: Plenum. 445p.

Borges, E.E.L. and Rena A.B. 1993. Germinação de sementes. In: Aguiar, I.B., Pinã-Rodrigues F.C.M. and Figliolia M.B. (eds.) Sementes florestais tropicais. pp. 83-135. Abrates, Brasília, Brazil.

Braccini, A.L. 1996. Germinação e vigor de sementes de soja sob estresse hídrico induzido por soluções de cloreto de sódio, manitol e polietilenoglicol. Revista Brasileira de Sementes 18:10-16.

Braga, L.F., Sousa M.P., Cesaro A.S., Lima G.P.P. and Gonçalves N.A. 2008. Germinação de sementes de pinho-cuiabano sob deficiência hídrica com diferentes agentes osmóticos. Scientia Forestalis 36:157-163.

Branco, R.H. 2000. Degradação de pastagens: Diminuição da produtividade com o tempo. Conceito de sustentabilidade. Editora UFV, Viçosa, Brazil. 126p.

Brasil. 2009. Regras para Análise de Sementes. SNAD/DNDV/CLAV, Ministério da Agricultura e da Reforma Agrária, Brasília, Brazil. 365p.

Carvalho, N.M. and Nakagawa J. 2000. Sementes: ciência, tecnologia e produção. 4.ed. FUNEP: Jaboticabal, Brazil. 588p.

Custódio, C.C. and Bomfim C.D. 2002. Estresse por alumínio e por acidez em cultivares de soja. Scientia Agricola 59:145153.

Dutra, S. and Souza-Filho A.P.S. 1998. Germinação de sementes de calopogônio (Calopogonium mucunoides). Pasturas Tropicales 20:30-39.

Embrapa. 2000. Estabelecimento, manejo e produção animal. In Comunicado Técnico 61, Estilosantes Campo Grande. pp.2-20. Embrapa: Campo Grande, Brazil.

Embrapa. 2002. Estilosantes Campo Grande: Situação Atual e Perspectivas. Embrapa: Campo Grande, Brazil. 20p. 
Faron, M.L., Perecin M.B., Lago A.A., Bovi A.O. and Maia N.B. 2004. Temperatura, nitrato de potássio e fotoperíodo na germinação de sementes de Hypericum perforatum L. e H. brasiliense Choisy. Bragantia 63:193-199.

Lopes, J.C. and Lima R.V. 2005. Germinação de sementes de urucu (Bixa orellana L.) em diferentes temperaturas e substratos. Informativo Abrates 15:202-209.

Macedo, G.A.R., Castro M.A.A., Campos S.R.F., Carvalho V.M. 2005. Importância da qualidade de sementes na formação e recuperação de pastagens. Informe Agropecuário 26:15-24.

Maguire, J.D. 1962. Speed of germination-aid in selection aid evolution for seedling emergence and vigor. Crop Science 2:176-177.

Marcos-Filho, J. 1994. Utilização de testes de vigor em programas de controle de qualidade de sementes. Informativo Abrates 4:33-35.

Marcos-Filho, J. 2005. Fisiologia de sementes de plantas cultivadas. FEALQ: Piracicaba, Brazil. 495p.

Mayer, A.M. and Poljakoff-Mayber, A. 1989. The germination of seeds. 4.ed. Pergamon Press: New York, USA. 270p.

Nobrega, R.S.A. and J.C.A. Nobrega. 2003. Fixação biológica do nitrogênio na recuperação de áreas degradadas e na produtividade de solos tropicais. Informe Agropecuário 24: 64-72.

Popinigis, F. 1985. Fisiologia da semente. 2.ed. Agriplan: Brasília, Brazil. 289p.

Purcino, H.M.A., Barcelos A.O., Verzignassi J.R., Aroeira L.J., Fernandes C.D. and Paciullo D.S.C. 2005. Utilização e contribuição de leguminosas na produção animal. Informe Agropecuário 26:76-96.

Prisco, J.T. 1978. Efeito da salinidade na germinação de sementes e no comportamento da plantas. In: Reunião sobre Salinidade em Áreas Irrigadas, 1978, Fortaleza. Anais... Fortaleza: Ministério do Interior, 64-72pp.

Roy, A.K., Sharma A. and Talukder G. 1988. Some aspects of aluminium toxicity in plants. Botanical Review 54:145-178.

Santos, V.L.M., Alil A.C., Ruiz H.A., Alvarenga E.M. and Santos C.M. 1992. Efeito do estresse salino e hídrico na germinação e vigor de sementes de soja. Revista Brasileira de Sementes 14:189-194.

Takaki, M. 2001. New proposal of classification of seed based on forms of phytochrome insted of photoblastism. Revista Brasileira de Fisiologia Vegetal 13:103-107.

Toledo, F.F. and Marcos-Filho J. 1977. Manual das sementes: tecnologia da produção. Agronômica Ceres: São Paulo, Brazil. 224p.

Torres, S.B., Vieira E.L. and Marcos-Filho J. 2000. Efeitos da salinidade na germinação e no desenvolvimento de plântulas de pepino. Revista Brasileira de Sementes 22:39-44.

Vasquez-Yanes, C. and Orozco-Segovia A. 1982. Seed germination of a tropical rain forest pioneer tree (Heliocarpus donnell Smithii) in response to diurnal fluctuations of temperature. Physiologia Plantarum 56:295-298.

Yamashita, O.M., Guimarães S.C., Silva J.L., Carvalho M.A.C. and Camargo M.F. 2009. Fatores ambientais sobre a germinação de Emilia sonchifolia. Planta Daninha 27:673-681. 